\title{
Is There a Future for Technology ?
}

THE report of the Working Group on Manpower for Scientific Growth under the chairmanship of Professor M. Swann, published on September 25 (HMSO, 17s. 6d.), makes sober reading.

If industry is to attract technically qualified people in the numbers which the national interest demands, there will have to be a radical re-examination of the whole educational system. According to the working group, the aims of the British educational system, at least as far as science and technology are concerned, should be to produce people well prepared for their prospective employment-especially in science-based industry and schools-and to produce people willing, even eager, to work in industry and the schools. The report says that the present educational system manifestly fails in the second of these aims and may well be failing in the first.

Industry and the schools, where demand is numerically greatest, have consistently failed to attract the best graduates (see Tables 1 and 2 ) and there is also now the swing away from science in the schools, revealed by the Dainton report. Even on the most optimistic assumptions, which provide for an increase of the ratio of sixth formers who go on to higher education from 63 per cent in 1966-67 to 75 per cent in 1971-72, the annual output of scientists will grow at less than 5 per cent per year compared with tho 10 per cent growth rate in the recent past (see Fig. 1).

Table 1. FIRST EMPLOYMENT OF FIRST DEGREE SCIENCE GRADUATES GRADUATING IN 1966

$\begin{array}{lcc} & \begin{array}{c}\text { First class } \\ \text { graduates }(\%)\end{array} & \begin{array}{c}\text { All } \\ \text { graduates }(\%)\end{array} \\ \text { Universities } & 72 & 34 \\ \text { Industry } & 9 & 25 \\ \text { Schools } & 7 \cdot 7(1962 ; 9 \cdot 7) & 19\end{array}$

Table 2. FIRST EMPLOYMENT OF FIRST DEGREE TECHNOLOGY GRADUATES GRADUATING IN 1966

First class All graduates $(\%)$ graduates $(\%)$

Universities

$45 \quad 18$

Industry

$38 \cdot 5$

$60 \cdot 5$

Schools

$2 \cdot 5$

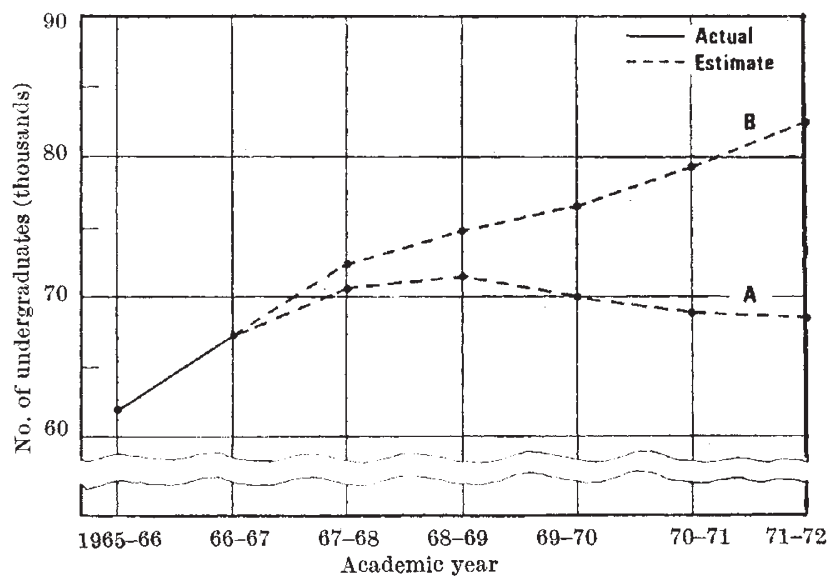

Fig. 1. Estimates of undergraduate university population in science and technology $(A)$ assuming no increase in proportion of sixth formers going on to higher education; $(B)$ assuming increase of proportion from $63 \%$ to $75 \%$.
Although the rate of growth of the numbers of scientists and technologists will decrease, the absolute numbers will rise, and if the proportion of these going on to postgraduate education remains constant at the present 43 per cent, the total postgraduate population will exceed that allowed for in the UGC quinquennial financial allotments. Inevitably, if the number of postgraduate students is not to decline, the universities will have either to find new sources of money or, as the report recommends, change their ideas on postgraduate education and resort to shorter courses.

The working group agrees with the UGC that it is in the national interest that undergraduate education should have priority over postgraduate education. It also reluctantly and perhaps surprisingly agrees that, given the trend away from science in the schools, the major increase in undergraduate places must be in the arts-based faculties. To maintain the growth of the number of graduate scientists and technologists, the first responsibility of the universities must be to accommodate qualified first degree applicants, even if at the expense of traditional postgraduate work.

Where will these graduates find jobs? Tables 1 and 2 show that, in 1966, 72 per cent of science graduates with first class degrees entered postgraduate education, while only 9 per cent went to industry. For graduates with all classes of degrees, the proportions are 34 per cent and 25 per cent respectively. The difference between science "firsts" and the rest entering school teaching is equally marked (see Table 1 ).

Industry is, of course, the chief employer of all technology graduates, but for those with first-class degrees it is only the second choice after research. Forty per cent of the "firsts" went into industry, compared with 60 per cent of all graduates. Obviously the overwhelming majority of scientists and technologists who are in a position to choose between research, industry and school-teaching choose research. Industry and the schools fail almost completely to attract the best graduates and it is the same story for people with higher degrees (see Table 3). Admittedly more postgraduate technologists enter industry than the universities and research, but the numbers have fallen since 1962 .

Table 3. FIRST EMPLOYMENT OF HIGHER DEGREE GRADUATES GRADUATING IN 1966

Science (\%) Technology $(\%)$

$\begin{array}{lrc}\text { Universities } & 35 & 23 \\ \text { Industry } & 12 & 31 \cdot 5(1962 ; 37 \cdot 5) \\ \text { Schools } & 7 & 4\end{array}$

The working group has bravely attempted to predict the long term need for scientists and technologists in schools and industry on the basis of discussions with industrialists, official statistics and a commissioned survey of the employment of graduates in Britain and the USA. Wisely, the group has confined itself to a discussion of overall trends. The outstanding feature of the survey is that British schools are living off their pre-war legacy of science graduates, and that the shortage of qualified science school masters will become even more acute unless something is done quickly (Table 4). In maintained schools, for example, 35 per cent of 
graduate mathematicians and 27 per cent of science graduates are more than fifty.

Table 4. AGE DISTRIBUTION OF SCIENCE SCHOOL MASTERS AND UNIVERSTTY TEACHFRS

$\begin{array}{ccc}\text { Age } & \begin{array}{c}\text { School } \\ \text { masters }(\%)\end{array} & \begin{array}{c}\text { University } \\ \text { teachers }(\%)\end{array} \\ \text { Under } 25 & 11 \cdot 8 & 2 \cdot 5 \\ 25-29 & 21 \cdot 9 & 20 \cdot 2 \\ 30-34 & 12 \cdot 1 & 22 \\ 35-39 & 10 \cdot 7 & 17 \cdot 7 \\ 40-44 & 6 \cdot 8 & 14 \cdot 9 \\ 45-49 & 6 \cdot 7 & 8 \cdot 5 \\ 50-54 & 11 \cdot 4 & 5 \cdot 8 \\ 55 \text { and over } & 18 \cdot 2 & 8 \cdot 3\end{array}$

Universities, by contrast, are going to be even more embarrassed by choice. Opportunities for employment in the universities are going to be many fewer in the current quinquennium than in the last. If the staff to student ratio does not change, and if the forward projection of the university populations is anywhere near accurate, the number of new university posts will increase by only 20 per cent in this quinquennium, just over half that of the past decade.

Professor Swann and his colleagues apparently had "less evidence than we could have wished for" for the assessment of industry's future needs. Industry's own forecasts are never certain because of changes in the economic climate, and the working group recognized that estimates of demand may reflect available supply as much as real need. But by comparison with the United States, and given British industry's recent history, the conclusion is that industry really does need more graduate scientists and technologists-especially bright ones. The difficulty, of course, is that industry's demands seldom coincide with the university courses, but the working group does take the view that specialist education in Britain discourages graduates from moving outside the fields in which they have been trained. How can the educational system be made more vocational and produce in its best people a willing. ness to enter industry and schools rather than almost exclusively higher education and research?

In the short term, the report recommends that $\mathrm{PhD}$ training should be more closely geared to industrial problems without decreasing intellectual content. The UGC, the research councils and the ministries should instigate these changes by manipulating their purse strings, according to the Swann committee. Industry must play its part by seconding staff to teach postgraduate courses, must become intimately associated with the research projects and will have to revise its opinion that $\mathrm{PhD}$ training is at best irrelevant and at worst a permanent alienation from itself and the schools. The $\mathrm{PhD}$ should be opened up to people working outside the universities, and the working group says it has been attracted to the idea of a professional doctorate, $\operatorname{PrD}$, of equal status and standard to the $\mathrm{PhD}$ but open to industrial scientists.

The working group is quick to emphasize that in the next few years there will be twice as many PhDs as new university jobs, so that industry has a unique chance of recruiting them by offering intellectually challenging work. There should also be a change in emphasis at the universities to shorter postgraduate courses and provision for training of graduates from industry in short specialist courses. In other words, the report urges much greater flexibility in postgraduate education, and the overthrow of the mutual distrust between universities and industry.

On the recruitment of teachers, the report considers that the easiest way to increase the flow of first class graduates and $\mathrm{PhDs}$ into the schools would be to create financial incentives; science teachers' pay should be increased, selectively if necessary. Experienced scientists or technologists, made redundant by rationalization in industry and Government research establishments, should be encouraged to move into teaching either by golden handshakes or payment of pensions before retirement age, and recently superannuated teachers should be re-employed. The other obstacle to recruitment is the emphasis on a formal teacher training, which adds an additional year to a graduate's training. The report suggests that teacher training should be included as an ancillary course during the usual three years of undergraduate study. Ways of bringing university teachers into school science teaching should also be explored, and Professor Swann and his colleagues make two suggestions-the use of university lecturers or even postgraduate students as locum tenens for teachers and lecture courses at schools or universities for sixth formers.

The working group admits that none of these measures really gets to the root of the problem. The British educational system, it says, is devoted to specialized rather than generalized education-as epitomized by the single subject specialization possible at Oxfordand specialist education tends to impede change. The working group therefore considers that the system will have to move towards the American pattern of a broad first degree followed, where necessary, by postgraduate specialization. The schools and the universities will have to cooperate in revising entrance requirements and sixth form teaching, and the working group believes that Oxford and Cambridge, with their great influence on the schools through the open entrance examinations, carry special responsibility for achieving a broadening of the whole of science education. It believes that the increasing numbers of sixth formers who take both arts and science subjects indicate that a broad rather than a specialist education would be welcomed by the students as well as being in the national interest.

Every university is asked to experiment with general courses for scientists; the Committee of Vice-Chancellors and the UGC are urged to examine science and engineering curricula in an attempt to broaden them. The working group also considers that the three year degree courses should be revised so that the general course is no longer considered a soft option. The group rejects on academic as well as economic grounds that if degree courses are generalized they should be lengthened.

The group also asks that industry should accept responsibility for mounting postgraduate courses and should be prepared to release its graduates from time to time, both to teach and to take postgraduate specialist courses. As a basis for discussion with industry, Professor Swann and his colleagues offer a career outline for the twentieth century man--a three year general degree course, with the emphasis on intellectual synthesis rather than analysis, a sixth month matching course for particular vocational training, three or four years in industry, a university course in some aspects of advanced technology, five or ten years in industry and finally a course in management. 